188

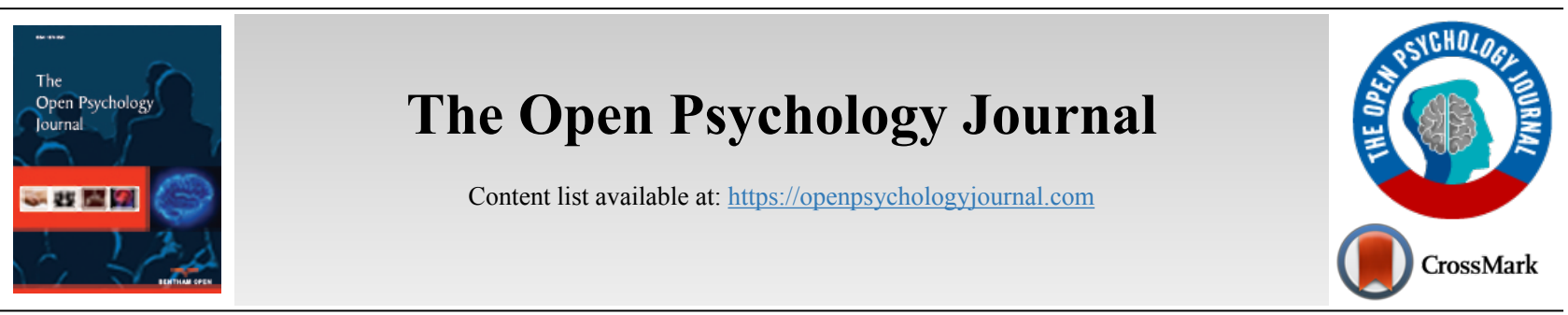

RESEARCH ARTICLE

\title{
Learning through Play: Improving the Reading Skills through the Joyful Phonetics of Pre-School Children
}

\author{
${\text { Taufik Taufik }{ }^{1, *} \text {, Suwarsi Suminto }}^{1}$, Rahimah Ibrahim $^{2}$ and Haslinda Abdullah ${ }^{2}$ \\ ${ }^{1}$ Faculty of Psychology, Universitas Muhammadiyah Surakarta, Surakarta, Indonesia \\ ${ }^{2}$ Faculty of Human Ecology, Universiti Putra Malaysia, Seri Kembangan, Malaysia
}

\begin{abstract}
:
Objective:

This study examined the role of a joyful phonetic method to improve reading skills of pre-school children in Indonesia

Materials and Methods:

Forty-seven pre-school children of age 4-5 years are involved in the study. Two criteria were used to select the participants of the study. Criteria included "they could not read" and "had never read". The Solomon three groups design was used to test the effectiveness of the treatment. There were one intervention group and two control groups. One of the control groups received the treatment and another one did not. Treatment included joyful learning so that participants did not realise that they were actually learning.

\section{Results:}

According to data analysis, (1) joyful phonetic improved the reading skills of the experimental group more than the control group 1 and (2) the joyful phonetic improved the reading skills of the control group 2 more than the control group 1 . Moreover, it was found that the phonetic, which had been given in the joyful condition, affects the improvement of the reading skills of pre-school children.

\section{Conclusion:}

The implication of the study is that the pre-school children would be more focused on the learning if the method has been conducted in a playing nature. Furthermore, pre-school children should be taught to read as they tend to begin their schooling.
\end{abstract}

Keywords: Reading, Phonetic, Pre-school children, Treatment, Schooling, Control group.

\section{INTRODUCTION}

According to the research, reading is considered as the foundation of learning. Researchers also defined reading as a process of thinking with the aim of understanding the reading content or authors' ideas [1]. There are generally four types of skills; listening, speaking, reading, and writing [2]. However, a skill that helps children to learn is the reading process [3]. It should be noted that at the primary reading level, letters are first introduced, which lead to understanding the meaning of words [4]. It also determines the children's ability at school and affects their academic achievement [5]. The ability to read is one of the tasks of students; moreover, all parties involved in the educational process at schools, such as teachers, caregivers,

"Address correspondence to this author at the Faculty of Psychology, Universitas Muhammadiyah Surakarta, Jl A. Yani, Tromol pos 1, Surakarta, Indonesia; Tel: 8156707945; E-mail: taufik@ums.ac.id and curriculum [6, 7] play a major role in this regard. Furthermore, reading can also be learned by involving parents, brothers, sisters, and other people living in the house [8]. To successfully obtain the reading achievement, the pre-school children should be supported by people around them, particularly parents by giving advice, providing facilities, and paying more attention to their success in the learning of how to read.

Researchers believe that for successful reading, parents should stimulate their pre-school children to start practicing the reading earlier in order to prepare them for school [9] so that when they enroll at the elementary school, they can follow the lessons well [10, 11]. According to Weigel, Lowman, \& Martin [12], the additional environment created at home and schools for effective development of the children's literacy has positive effects on the achievement of their reading skills. During their 
critical period (i.e., 0-6 years), children's brain development is characterized by the accelerated ability to show the nature of "blooming" accompanied by changes in the body anatomy and rapid physiological functions [13]. This is an important period because it becomes the basis of various developmental aspects to strengthen their cognitive capability [14]. Therefore, early reading ability is important for children to succeed at school.

As a basis of language skills, the ability to read not only enables the children to understand the reading content but also affects their language skills $[14,15]$. Children's language skills and vocabulary mastery help them to receive and convey information [16] and allow them to think about different objects and events surrounding them. The language also becomes a foundation for social interaction and verbal communication. At this stage, the children express their thoughts and receive new information that has been not previously understood [17]. It is widely accepted that reading skill affects the children's capability in many aspects, namely cognitive ability, language skill, and social relationships, including children's parents and friends.

According to the researchers, children are individuals who continually are ready to learn as long as their parents provide them an opportunity [16]. Thus, appropriate stimulation can enhance children's developmental dimensions, but inappropriate stimulus produces bad results $[18,19]$. However, parents cannot force children to learn because they have not yet understood the meaning of responsibility or task [18]. Nevertheless, there are many parents spending hours per day on holding cue cards to increase their children's vocabulary. This kind of pressure can be a barrier to the children's intellectual development, the establishment of a passive learning process, and the production of unexpected results [20]. Therefore, parents should provide a conducive situation so that children are comfortable with learning assignments.

With regard to the research results, in critical periods (i.e., 2-5 years), children need to learn many things such as reading [21]. However, implementation of the teaching and learning for children requires considering the principle of children's learning; that is, fun learning [22]. One of the studies in the field defined joyful learning as a learning method that involves positive emotions such as feeling joy, happy, and comfortable for students [23]. Another study argued that the teacher tries to provide an enjoyable atmosphere during the learning process by using interesting methods so that students (children) feel enthusiastic to take part in the learning. The impact of such learning is that children would feel happy, comfortable, free to explore, and free to express themselves by playing. Hence, learning will be more effective [22]. As stated by the researchers, joyful learning can reduce children's anxiety of being under pressure, eliminate boredom, and ultimately lead to an effective learning process [24]. Researchers illustrated that joyful learning takes place by playing, so children do not realize that they are actually learning [20]. Likewise, in early reading learning, a pleasant atmosphere can eliminate boredom and increase children's enthusiasm to continue learning. This learning method is known as the joyful phonetics.

Based on the results, phonetics is a branch of linguistics that deals with the human ability to convey information [24].
Some research stated that phonetics is a method of teaching reading that is adapted to the principles of early childhood learning [25]. It is also a method that teaches letter sounds and then associates each letter sound with meaningful words and pictures through telling stories [26]. It should be noted that the teacher delivers learning material in a fun way in the learning process. It is marked by the expression of smile, patience, and friendliness [27]. In addition, the teacher can deliver the material by singing accompanied by a funny face or a happy mimic. While "singing", the teacher can appoint one of the children to answer how to read letters and children will also respond by singing [25 - 27]. Finally, this method makes learning context dynamic and the children will also feel comfortable during the learning process.

As demonstrated by researchers, learning reading through joyful phonetics provides an opportunity for children to be active and expressive. It is also supported by an interesting teaching strategy to hinder children's boredom so that they are encouraged to continue reading. Notably, the rate of the success of the phonetics application would be indicated by three elements of phonological awareness, orthographic understanding, and word learning [28]. A study in the field argued that the first and second elements deal with the knowledge aspect, while the third element is a form of support for the first and second elements. In addition, the phonetics accommodates children to all types of learning styles, including visual, auditory, and kinesthetic styles [29]. Therefore, it can create more effective teaching methods of reading skills and indicate that teachers should establish effective teaching styles so that when they provide learning activities, the children can easily learn.

According to the studies result, children are more dominated by physical activities in early childhood [30]. Notably, they would make a lot of improvements in gross motor skills such as rolling, running, and jumping. Research showed that children become physically stronger and thus they can play harder. However, all of their activities just focus on the activities that they are playing. Such a situation makes children ignore their new responsibility (i.e., learning). Learning to read is one of the early learning stages because reading is as an initial preparation to enter the school context. Thus, the nature of playing should be fun, but the nature of reading learning needs seriousness [16]. On the other hand, children like to play, yet they need to focus on lessons. Moreover, they cannot automatically change themselves in different situations. Therefore, a method should be developed to bridge the gaps for creating a learning method in the playing atmosphere. Furthermore, children can suggest different types of games that accompany learning activities. Such a condition is usually referred to as student-directed learning. The present study proposed joyful phonetics as a reading learning method that combines two elements, namely game and learning. Thus, children can learn without feeling depressed and tiredness as they are subjected to a pleasant atmosphere. Therefore, the main question of the study addresses: Does joyful phonetics affect the improvement of the reading skills in children.

It is notable that the present study included two variables of reading skills as a dependent variable and joyful phonetics 
as an independent variable. In other words, joyful phonetics was used as a treatment to improve reading skills. Thus, the novelty of the study is related to the modification of both dependent and independent variables. In fact, the reading skill applied the Early Reading Screening Instrument (ERSI), originally in English, but researchers modified it to have an Indonesian language version. Therefore, the joyful phonetics was modified from the suggested phonetic method to train children to read; however, the present study combined it with joyful nuances, such as singing songs about studied letters.

Effectiveness of a joyful phonetic method in the improvement of the children's reading skills was emphasized in the present study. Thus, the study included two specific objectives. 1. Examining the levels of pre-school's reading skill in the experimental and control group 1 (pre-test and post-test). 2. Examining differences in the post-test scores of the control group 1 and only the post-test scores of the control group 2 (only post-test).

\section{METHODS}

This is a quasi-experimental research with pre-test and post-test control groups. Dependent variable included reading skills and the independent variable was joyful phonetics. The quasi-experimental was conducted using Three Group Solomon Design [31, 32]. It should be noted that the design was implemented by conducting an initial observation before and after the intervention of experimental and control groups. Moreover, there were three groups in the present study, including experimental group, control group 1, and control group 2. The group members were selected randomly. The Experimental Group (EG) received the pre-test and post-test and was taught reading skill using the phonetic method. The control group 1 (CG1) received pre-post tests without any treatment and the control group 2 (CG2) received only the post-test and the joyful phonetics treatment.

As demonstrated by Table 1, the measurement was performed before the treatment to know initial levels of respondents in the Experimental Group (EG). Then, the group received a treatment, in which they were taught reading skills using the phonetics. Moreover, a post-test was provided to see if there were any differences before and after the treatment or not. In the Control Group 1 (CG1), the measurement was done twice, namely pre-test and post-test, but this group did not receive any treatment i.e., after completing the experiment, participants received the treatment. Finally, in the Control Group 2 (CG2), respondents did not get the pre-test, but they received the treatment, in which they were taught to read using phonetics, and then they received the post-test. The control group 2 aimed at ensuring the fact that improvement of the respondents' reading skills results from the effect of the treatment not the effect of other factors such as maturity or they should be tested once by using the same test instrument in the present study.

\subsection{Participants}

The research sample icludes 47 children aged 4-6 years in Surakarta, Indonesia. The participants spoke Javanese in their daily life, but they were trained to read (as a treatment) in Bahasa Indonesia. It should be noted that selecting participants involved three steps in several stages, starting from the first stage, which was screening the reading ability. The selected participants could not read and have never learned to read. Information was obtained through interviews with parents. After the participants passed in the first stage, it continued to the second stage; that is, the screening of the children' reading skill, by which children were asked to recognize 13 alphabet letters. The process of screening used 1 and 0 scoring system. If respondents provided correct answers, they would get 1 point. Otherwise, if their answers were incorrect, they would get 0 . The last step or the third stage was screening through CPM intelligence test that was used to make sure that participants had the same level of intelligence (on average) because the treatment to be given might be difficult for children with special needs. All of 47 participants were divided into 3 groups in random assignment with the composition of experimental group $=16$ participants, control group $1=16$ participants, and control group $2=15$ participants.

\subsection{Instrument}

Morris administered the reading ability test using the Early Reading Screening Instrument (ERSI) [32]. In fact, ERSI was used to measure English reading ability. However, the present study modified ERSI to measure the reading ability in the Indonesian Language. Moreover, as stated by researchers, the back-translation of ERSI scale was used in the study. The back translation means taking protocols from a study in a particular language, translating it into other languages, and asking others to translate it again into their native languages [33]. This method was chosen to prevent bias [34]. The steps were as follows: 1) Translating ERSI scale from English into Bahasa Indonesia, 2) Translating ERSI scale from the Bahasa Indonesia into English, and 3) Decentering, which is general processing of concepts and language from two different languages [31]. At this stage, the researcher was assisted by a native speaker to compare the translation results of ERSI (in English). The method was implemented to see the equality between ERSI back translation results with the original ERSI version. If there were unequal words or different meanings and nuances, the researcher re-checked the ERSI translation results (in Bahasa Indonesia), and then the researcher fixed them.

Table 1. The three groups solomon design.

\begin{tabular}{|c|c|c|c|c|}
\hline RA & Groups & Pre-test & Treatment & Post-test \\
\hline $\mathrm{R}$ & Experimental (EG) & 01 & $(\mathrm{X})$ & 02 \\
\hline $\mathrm{R}$ & Control (CG1) & 01 & $(-)$ & 02 \\
\hline $\mathrm{R}$ & Control (CG2) & & $(\mathrm{X})$ & 02 \\
\hline
\end{tabular}

Note: R: Random Assignment; (X): treatment; (-): no treatment 
Table 2. Reading ability aspects.

\begin{tabular}{|c|c|c|c|}
\hline No. & Aspects & Questions & Number of Items \\
\hline 1 & Letter recognition of words started by certain letters & $s, a, t, u, p, d, k, o, b, e, l, i, m$ & 13 \\
\hline 2 & Phonemic awareness & Sapu, tali, pita, desa, kopi, soto, lidi, mete, opa, ibu & 10 \\
\hline 3 & The ability to read words & aku, dadu, pipa, paku, kaki, siti, itu, suka, susu, kaka & 10 \\
\hline 4 & Words concept in a text & $\begin{array}{c}\text { 1. Halo, namaku Dika (Hello, my name is Dika) } \\
\text { 2. Kata mama, aku anak pintar (Mom says, I am clever) } \\
\text { 3. Aku suka membaca buku (I like read a book) } \\
\text { 4. Papa mengajakku ke toko buku (Daddy accompany me to bookstore) }\end{array}$ & 18 \\
\hline 5 & The ability to write the letters (letter formation) & $s, a, t, u, p, d, k, o, b, e, l, i, m$ & 13 \\
\hline \multicolumn{3}{|r|}{ Total } & 64 \\
\hline
\end{tabular}

Notably, ERSI was used to predict the reading ability of grade 1 students in elementary school. The validity of the instrument was examined by the opinions and judgments of the experts. Moreover, reliability was tested by the Kappa coefficient from Cohen with a coefficient value 0.7. According to Fleiss [35], Kappa coefficient value 0.7 is categorized as good. The test instrument covered 5 aspects such as letter recognition, letter formation, word concept in text, phonemic awareness, and the ability to read words. The higher the score in the test, the better their reading ability. In contrast, the lower scores indicated the lower reading ability. Table 2 presents the reading ability aspects.

The following procedures were used to score the aspects. 1) Recognizing words that start with certain letters; children got 1 point if they could name the intended words, and got 0 if they could not mention the words. 2) Phonemic awareness; children got 1 point if they could utter initial or final sounds of the intended words, and got 0 if they were unable to sound initial and final sounds of the spoken words by the trainer.
3) The ability to read words; children got a score of 3 if they could read words, and got 0 if they could not read it. 4) The word concept within the text; the children were asked to follow as the trainer read 4 sentences in a simple story and then were requested to match the spoken words with the written ones. This aspect measured their ability to determine whether the words are correctly read. They got 1 if they pointed to the correct words and got 0 if the answers were incorrect. 5) The ability to write letters; the children got 1 point if they could write letters in the right way and correct forms, and got 0 if they could not write letters in the correct forms and ways.

\subsection{Procedures}

It is mentioned that the present experimental study was conducted for 18 days in sequence. 1. A pre-test was given on the first day, 2) The treatment was implemented from day 2 to 17 (treatment was received in 16 sessions, by which each session lasted for 1 hour), and 3) The post-test was implemented on the day 18. Fig. (1) shows the research stages.

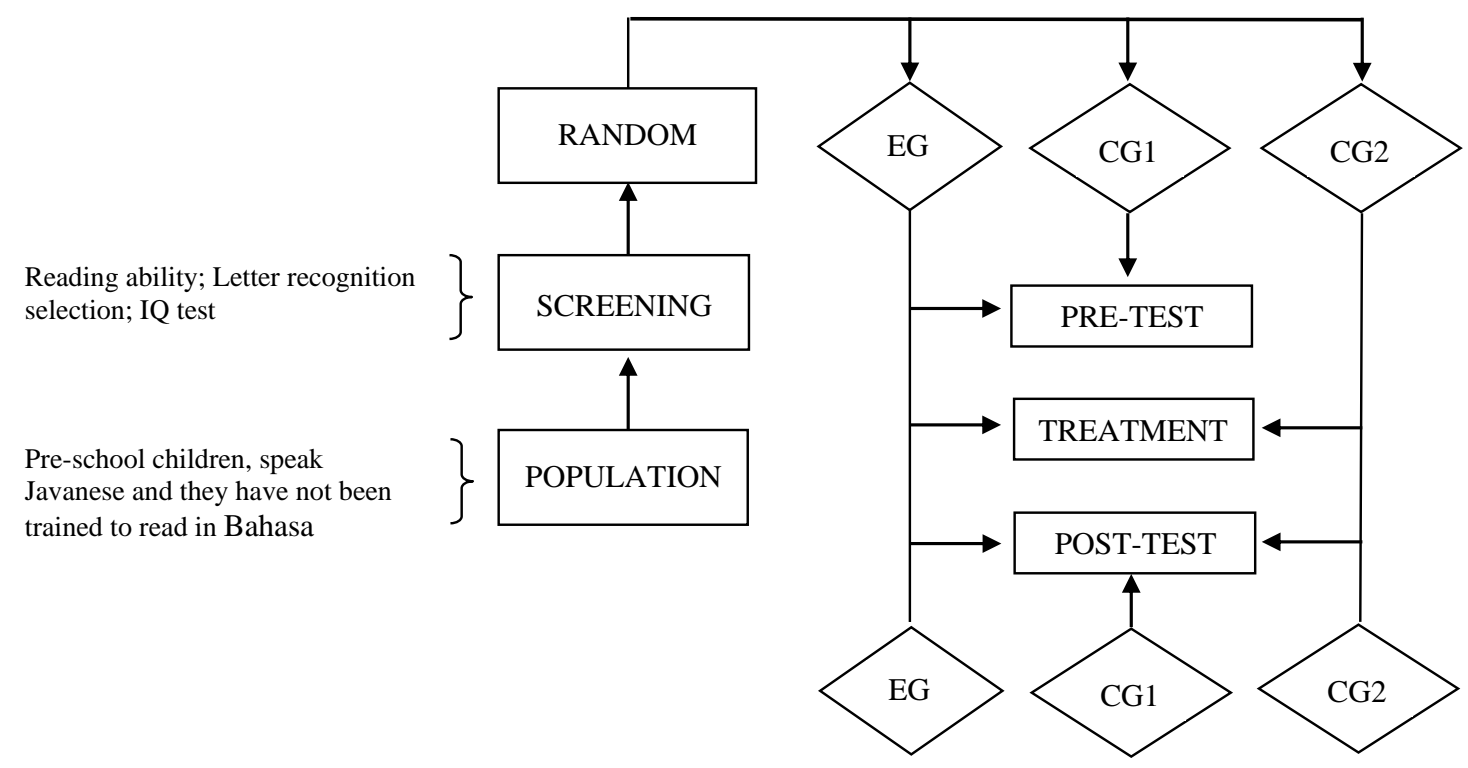

Fig. (1). Research procedures. 
[1] Screening. The screening was performed to determine the subject conditions before doing the research. In this case, the condition refers to the level of intelligence (by SPM) and the ability to recognize letters. Therefore, the results of the screening process were used as a reference in the selection of the participants for both experimental and control groups.

[2] Randomization. This concept refers to the selection of the participants in a random manner. It aimed at controlling the secondary variable both in the experimental and control groups 1 , so that both groups were equal.

[3] Pre-test. This stage used a worksheet containing several items to reveal 5 aspects, namely recognizing simple words that start with a certain letter, writing skills, phonemic awareness, word recognition, and word concepts in reading. This pre-test was implemented with the aim of understanding the initial score of initial reading ability in the participants of the experimental group and control group 1 .

[4] Treatment. The treatment was provided as the teaching of reading through phonetics for participants in the experimental group and control group 2. The treatment received 16 sessions for 16 days. A session was performed for 30 minutes.

[5] Post-test. This test was implemented for participants in the experimental group, control group 1, and control group 2 after being treated in terms of learning reading using the phonetics. It should be noted that the same worksheets were used in the post-test and pre-test. However, post-test was implemented with the aim of finding differences of initial reading ability before and after the treated experimental group and control group 2 as well as the understanding of the differences of initial reading ability of the experimental group, control group 1, and control group 2.

\subsection{Joyful Phonetics as the Treatment}

Interestingly, researchers developed the phonetics in joyful nuance. The joyful situation was on the basis of four dimensions: conditioning in the early session, teaching the material, asking questions, and answering children' questions [36]. These four aspects created an atmosphere of excitement for children so that they did not feel depressed. For example, the following steps teach letter recognition to children:

[1] The children were invited to sing the popular songs ("Balonku" = My balloons and "Pelangi" = Rainbow) with a focus on the instructor.

[2] After the children paid attention to the instructor, the instructor showed a card that had two sides. The first side contained a letter, which should be taught and the other side was related to an object image that had the same prefix with a letter, which should be taught. Under the object image, there was the object name; for example, the word "mama" in one side and "mama" image on the other side.

[3] While showing the object image side, the instructor pronounced the letters three times and they were imitated by children. For example, in the word "mama", letter "m" was mentioned three times.

[4] The instructor told about the object image that was associated with the children's direct experience (about mama).

[5] The instructor wrote letters with a finger in the children's palm three times while singing the song of a letter (letter "m").

[6] The instructor showed the letter side that was taught by asking them "what letter is this?". The children answered: "m".

[7] The instructor asked what words began with the same letter as the word that was taught. The word "mama" has the prefix " $\mathrm{m}$ ". Thus, the instructor asked children to mention other objects with the prefix " $m$ ", for example, "mata" (eyes), "meja" (table), and so on.

[8] The words mentioned by children were written on the board and the letters were then introduced to children in order to arrange the word.

[9] The instructor asked children to complete the words by writing the letters on the word, in which the front letter was omitted.

[10] These steps were repeated for other cards.

\subsection{Data Analysis}

This study examined the differences in the effectiveness of joyful phonetics for improving reading skills in the pre-school children by pairing sample t-test and independent sample t-test. There were two pre-requisite tests before the t-test, including normality test with Kolmogorov-Smirnov and Levene's Test for Equality. Moreover, t-test was run three times with the aim of 1. Comparing the scores of the joyful phonetics between pre-test and post-test of the experiment group, 2. Comparing the scores of the joyful phonetics between pre-test and post-test of the control group 1, and 3. Comparing the scores of the joyful phonetics between the post-test of the control group 1 and post-test of the control group 2. The third comparison was made to ensure that the treatment (joyful phonetics) affects the improvement of the reading skills. The whole data were analyzed by SPSS 23 .

\section{RESULTS}

It should be mentioned that the paired sample t-test was implemented to determine whether levels of reading skills of pre-school children showed a significant difference according to the comparison between the experimental group and control group 1.

According to Table 3, the t-test score of the experimental group is -4.798 that is significant at $p=0.00$. However, there was a difference between the mean score of pre-test $=29.19$ and post-test $=47.75$, with a mean distance at -18.56 . Accordingly, analyzing the paired sample t-test of the control group 1 indicated that the comparison between pre-test and post-test of control group 1 is not significant $(\mathrm{t}=-0.120, p=$ 0.906). According to results, without the treatment, reading skill of participants did not change. Thus, the treatment (joyful phonetics) affected the improvement of the reading skills ability of the participants. 
Table 3. Examination of pre-school's reading skill levels on the experimental group and control group 1.

\begin{tabular}{|c|c|c|c|c|c|c|c|c|}
\hline \multirow{2}{*}{ Groups } & \multicolumn{4}{|c|}{ Paired Differences } & \multirow{2}{*}{ t } & \multirow{2}{*}{ df } \\
\cline { 2 - 7 } & Sig. \\
\hline Paired Experimental Group Pre-Post & 29.19 & 47.75 & -18.56 & 15.581 & 3.895 & -4.798 & 15 & 0.000 \\
\hline Paired Control Group 1 Pre-post & 31.50 & 31.81 & -.313 & 10.410 & 2.602 & -0.120 & 15 & 0.906 \\
\hline
\end{tabular}

It should be noted that according to a Three Group Solomon Design, the control group 2 should examine whether the treatment is effective due to the treatment and not due to other factors to find the consistency of comparison results between the experimental group and control group1. In other words, the initial reading ability increased in the children because of the influence of joyful phonetics that should be tested by comparing the results of post-test of control group 1 and the control group 2. If the post-test results of the control group 2 are better than the control group 1, then it could be concluded that the effectiveness results from the effect of treatment and not due to other factors. Hence, the results of the independent sample t-test from the post-test activity of control group 1 and control group 2 are presented as follows:

According to Table 4, the t-test score was $-2,689$ at degree 14 greater than the value of t-table. As observed, it is significant at $p<0.05$. Based on the results, it is concluded that there is a difference between post-test scores in the control groups 1 and 2. The post-test score of control group 2 is significantly higher than the post-test score of control group 1 . It should be noted that the result confirmed the previous findings (Table 3) that the treatment is effective.

Based on the results of the paired t-test, the pre-test and post-test scores in the experimental group obtained $\mathrm{t}=-4.798$ at a significance level of $p<0.05$. The pre-test and post-test scores of control group 1 obtained $\mathrm{t}=-0.120$ with a significance level of $p>0.05$. Moreover, post-test scores of the control groups 1 and 2 obtained $\mathrm{t}=-2,689$ at the significance level of $p<0.05$. The results indicated strong evidence that there are significant differences between the participant group with and without the treatment. Finally, data analysis confirmed that the joyful phonetics is effective in improving the reading skill ability. Table 5 presents a summary of the paired t-test results.

Table 5 reports a summary of all results. The most surprising correlation was shown by post-test scores of the experiment group and control group 2 because the mean posttest score of the experiment group was 47.75 and mean posttest score of the control group 2 was 48.60 . Moreover, the t-test score of both groups was significant $(p<.05)$. Thus, it could be re-concluded that the treatment is effective in the improvement of the reading skill ability of pre-school children.

\section{DISCUSSION}

According to the studies, the Javanese people are known as subtle people with positive characters such as gentle, smiling, friendly, and polite in terms of words and behaviors with both familiar people and foreigners [37, 38]. They also communicate using languages with different levels depending on who speaks [38]. However, such subtle community characters need a subtle approach so that the message delivered would be more easily accepted. Similarly, learning must be delivered in a way that is friendly, fun, and non-coercive [39], so that the Javanese children can receive easy learning using joyful learning without realizing that they are actually in the learning process, including reading learning.

One of the previous research of the early reading on the Javanese pre-school children focused on the methods without considering any cultural aspect. It dealt with the early reading of pre-school children using media images [40]. Another study addressed early reading learning through spelling methods for students with reading difficulties [41]. Some researchers emphasized on the increase of the initial reading skills through constructivism learning and the use of flannel boards [42]. However, a number of research indicated higher early reading by using the maze method [43]. Regarding the research themes, it could be seen that the character and cultural aspects have been not considered in previous studies. According to Akubuilo et al. [2], the early reading ability is largely determined by the character of community and habits in the family. This means that the surrounding community and its characters underlie the children smooth learning of reading. Therefore, the present study aimed to explore the values of local wisdom of the Javanese people, namely subtle and friendly wisdom, as one of the important components of the treatment to improve the early reading ability of pre-school children.

Table 4. Independent sample t-test of the control group 1 and control group 2.

\begin{tabular}{|c|c|c|c|c|c|c|}
\hline Groups & Mean Dist. & SD & Std. Error Mean & t & df & Sig. \\
\hline Independent CG1 and CG2 (posttest only) & -15.07 & 21.704 & 5.604 & -2.689 & 14 & 0.018 \\
\hline
\end{tabular}

Table 5. Summary of the paired t-test results.

\begin{tabular}{|c|c|c|c|c|c|}
\hline No & Group & Mean Pre-Test & Mean Post-Test & t & Sig. \\
\hline 1 & EGpre-post & 29.19 & 47.75 & -4.798 & 0.000 \\
2 & CG1pre-pos & 31.50 & 31.81 & -0.120 & 0.906 \\
3 & CG1post-CG2post & & 48.60 & -2.689 & 0.018 \\
\hline
\end{tabular}


Data analysis showed that joyful phonetics is effective in improving children's reading skills. The joyful learning is a companion force of affective elements that can attract children's attention to focus on the taught materials. Moreover, learning to read with joyful phonetics results in positive characters that help the learning process, such as generating imagination, increasing enthusiasm, and motivating children to stay focused on the learning process $[44,45]$. Therefore, the teacher plays a very strategic role in this regard. The teacher must be able to create an encouraging context so that children remain enthusiastic about learning [46]. Hence, in a case of the use of joyful learning, children can implement holistic learning, including multiple cognitive, emotional, and social aspects to make the learning process more effective.

It should be noted that the research results were in accordance with the opinions of various experts who argued that a factor leading to effective reading teaching is achieved when teaching is carried out in balance between the emphasis on the word elements or emphasis on the small units of letters [47] and the emphasis on the context of word meaning [48]. However, word emphasis is one of the important aspects of vocabulary knowledge [49]. Other studies believed that during the learning process, children can store the meaning of words, including positions where syllable emphasis is on their memories [50].

As stated by researchers, the joyful phonetics stage starts with phonological recognition, in which a response to the sounds is conveyed by the teacher as a sign that the children have phonological awareness and has strong and specific relationships with the initial understanding of reading [51], [52]. In fact, when children listen to the words spoken by a teacher, they must be able to distinguish variability in speech signals and classify signals into smaller units, so that they easily understand them [53]. In other words, children firstly acquire basic decoding skills and gradually apply these skills with greater accuracy and speed, which leads to automatic processes in recognizing multi-letter units (consonant groups, syllables, and morpheme) and all words [54]. Thus, children with phonological awareness have a higher potential to become competent readers [17].

Studies showed that joyful phonetics is the teaching methods that practice phonological awareness of children. Therefore, children's ability to learn reading is affected by how far the phonological awareness of children is [55]. Moreover, phonological awareness refers to the awareness of the sound structure of the spoken words in a particular language [56]. Thus, children recognize syllables that form a word from the initial introduction to sound awareness. After recognizing words, children understand that several joined words will form a sentence [55]. Hence, phonological awareness is significantly related to children's hearing [57]. However, children who experience difficulties in phonological processing would be disrupted in the process of understanding [58].

It is widely accepted that the ability to distinguish phonemes is a prediction of children's ability to read successfully. Phonetic awareness helps children to understand that the sound is represented in letters. However, the higher the sound awareness and phoneme awareness of children, the faster children would be able to read [55]. Consequently, children with better ability to change syllables and phonemes are better in learning to read than those with difficulty in acquiring these skills. As a result, there is a unique relationship between phonological awareness and ability to read words [59].

One of the studies indicated important findings of phonemic awareness so that phonemic awareness is very effective to be used in learning to read, particularly in learning to interpret words. Therefore, children, who are able to hear various sounds in words and use sounds in words, are more successful in learning to read. In other words, if several opportunities are provided with the children to play with language and hear sounds in words, their phonemic awareness skills would be developed [52].

The present study also revealed that when children are not introduced to the sound and shape of letters, they would hardly recognize the sound and shape of letters as letters are strung together in words. Based on the pretest results, the researchers identified children who do not know the sound of initial letters of words (phonemic awareness). In fact, when the children were asked "what is the initial letter sound on the word "padi"?, a student answered "pa". After being investigated, the researchers found that the students learn to read by a syllable method that has been not previously introduced to letters. Practically, reading by syllable method could lead students to read; however, children would still have difficulty to read a single consonant in a certain time. Finally, it was found that the joyful phonetic is an appropriate method for teaching reading to the pre-school students.

\section{CONCLUSION}

As confirmed by the results, the joyful phonetics treatment affects the improvement of the reading skills in pre-school children. It was demonstrated that the joyful phonetics is similar to a magnet that can attract children's attention so that they would not easily get bored and depressed in the learning process. Moreover, it makes children more attentive to learn. In addition, it can trigger children to have phonological awareness. Both joyful and phonological awarenesses were a combination of two complementary elements of the joyful awareness intended to address the affective aspects and phonological awareness as a cognitive aspect. Thus, a combination of both leads to the children's attention so that they focus on what is taught. In this case, they learn to read. It should be noted that integrative methods (cognitive and affective aspects) are effective for supporting the reading learning methodes for children. Therefore, the study concluded that parents should be trained for early reading teaching using joyful phonetics so that they can teach their children to read before they enter elementary school.

\section{ETHICS APPROVAL AND CONSENT FOR PARTICIPATION}

This study was ethically approved and licensed by Universitas Muhammadiyah Surakarta Research Institute, and the study was conducted according to APA ethical standards. 


\section{HUMAN AND ANIMAL RIGHTS}

No animals were used in this research. All human research procedures that were followed were in accordance with the ethical standards of the committee responsible for human experimentation, and with the Helsinki Declaration of 1975 as revised in 2013.

\section{CONSENT FOR PUBLICATION}

Not applicable.

\section{AVAILABILITY OF DATA AND MATERIALS}

Not applicable.

\section{FUNDING}

None.

\section{CONFLICT OF INTEREST}

The authors confirmed that the present paper had no conflict of interest.

\section{ACKNOWLEDGEMENTS}

Declared none.

\section{REFERENCES}

[1] Shihab IA. Reading as critical thinking. Asian Soc Sci 2011; 7(8): 209-18.

[http://dx.doi.org/10.5539/ass.v7n8p209]

[2] Akubuilo F, Okorie EU, Onwuka G, Uloh-Bethels AC. Reading readiness deficiency in children: Causes and ways of improvement. J Educ Pract 2015.

[3] Branch L, Street V. How can students improve their reading comprehension skill?. 2016; 6.(2)229

[4] Tarigan HG. Membaca sebagai suatu keterampilan berbahasa (Reading as a language skill). Bandung: Angkasa 2008.

[5] Mwoma T. Children's reading ability in early primary schooling: Challenges for a Kenyan rural community. Issues Educ Res 2017; 27(2): 347-64

[6] Suggate SP, Schaughency EA, Reese E. Children learning to read later catch up to children reading earlier. Early Child Res Q 2013; 28(1): $33-48$.

[http://dx.doi.org/10.1016/j.ecresq.2012.04.004]

[7] Huemer S, Landerl K, Aro M, Lyytinen H. Training reading fluency among poor readers of German: Many ways to the goal. Ann Dyslexia 2008; 58(2): 115-37.

[http://dx.doi.org/10.1007/s11881-008-0017-2] [PMID: 18777137]

[8] Nguyen THT, Khuat NTT, Huyen KTT, Th N. Th, \& Nga, "Learning vocabulary through games. Asian EFL J 2003.

[9] Gullo DF. K today: Teaching and learning in the kindergarten year. Washington, DC: National Association for the Education of Young Children 2006.

[10] Torgesen JK. Individual differences in response to early interventions in reading: The lingering problem of treatment resisters. Learn Disabil Res Pract 2004; 15(1): 55-64.

[http://dx.doi.org/10.1207/SLDRP1501 6]

[11] Wagner RK, Torgesen JK. The nature of phonological processing and its causal role in the acquisition of reading skills. Psychol Bull 1987; 101(2): 192-212

[http://dx.doi.org/10.1037/0033-2909.101.2.192]

[12] Weigel DJ, Lowman JL, Martin SS. Language development in the years before school: A comparison of developmental assets in home and child care settings. Early Child Dev Care 2007; 177(6-7): 719-34. [http://dx.doi.org/10.1080/03004430701379173]

[13] Brown TT, Jernigan TL. Brain Development During the Preschool Years. 2012; pp. 313-33.

[14] Mann VA. Reading skill and language skill. Dev Rev 1984; 4(1): 1-15. [http://dx.doi.org/10.1016/0273-2297(84)90014-5]

[15] Mart CT. Developing speaking skills through reading. Int J Engl
Linguist 2012; 2(6): 91-6.

[http://dx.doi.org/10.5539/ijel.v2n6p91]

[16] Powell PJ. The messiness of readiness. Phi Delta Kappan 2010; 92(3): 26-8.

[http://dx.doi.org/10.1177/003172171009200307]

[17] Ormrod J. Psikologi pendidikan membantu siswa tumbuh dan berkembang (Educational psychology: Helping students grow and develop). Jakarta: Erlangga 2008.

[18] Masnan AH, Haziq M, Sharif M, Josin EH. Preschool teachers , professionalism through developmentally appropriate practices (DAP). Curriculum 2018; 1(5): 20-5.

[19] Monks SR. FJ, Knoers, AMP, \& Haditono, Developmental psychology. Yogyakarta: Gajah Mada University Press 2004.

[20] Santrock JW. Child Development. 14th ed. New York, NY: McGrawHill Education 2013.

[21] Lillard AS, Lemer MD, Hopkins EJ, Dore RA, Smith ED, Palmquist $\mathrm{CM}$. The impact of pretend play on children's development : A review of the evidence. Psychol Bull 2013; 139(1)

[22] Paramitha S T. Influence of Joyful Learning on Elementary School Students' Attitudes Toward Science. J Phys Conf 2017.

[23] Using Active , Creative , Effective and Joyful ( ACEJ ) Learning Strategies toward English Achievement and their Behavioural Changes among Primary School Students Abdullah Hasan Zarina Othman Rohaty Mohd Majzub MedJ Soc Sa 2015; 6(6): 455-9.

[24] Ball MJ, Müller N. The use of the terms phonetics and phonology in the description of disordered speech. Int J Speech Lang Pathol 2002; 4(2): 95-108

[http://dx.doi.org/10.1080/14417040210001669321]

[25] Rooney T. Understanding of contemporary vocal pedagogy and the teaching methods of internationally acclaimed vocal coaches Int \& Learn Tech Edu Res 2016; 15(10): 147-62.

[26] Mustafa S. Teacher views about using songs in teaching English to young learners. 2011; 6: pp. (21)1027-35.

[27] Johnson CS, Thomas AT. Caring as Classroom Practice 2009; 22(1): 8-11.

[28] Fountas IC, Pinnell GS. How and Why Children Learn about Sounds. Letters, and Words in Reading Recovery Lessons 1998.

[29] Scott C. The enduring appeal of 'learning styles,'. 2010; 54: pp. (1) $5-17$.

[http://dx.doi.org/10.1177/000494411005400102]

[30] Bidzan-Bluma I, Lipowska M. Physical activity and cognitive functioning of children: A systematic review. Int J Environ Res Public Health 2018; 15(4)E800

[http://dx.doi.org/10.3390/ijerph15040800] [PMID: 29671803]

[31] Kirk RE. Experimental design: Procedure for the behavioural sciences. 4th ed. London: Sage Publications, Ltd. 2013.

[http://dx.doi.org/10.4135/9781483384733]

[32] Moreira T, Foxcroft DR. The effectiveness of brief personalized normative feedback in reducing alcohol-related problems amongs university students: Protocol for a randomized controlled trial. BMC Public Health 2008; 8: 113.

[http://dx.doi.org/10.1186/1471-2458-8-113] [PMID: 18402657]

[33] Ross S, et al. Children's perspectives of play and learning for educational practice. Educ Sci 2015; 5(4): 345-62.

[http://dx.doi.org/10.3390/educsci5040345]

[34] Matsumoto L. D, \& Juang, Culture and psychology. 5th ed. Belmont, CA: Wadsworth Cangage Learning 2013.

[35] Society IB. Measuring Agreement between Two Judges on the Presence or Absence of a Trait Author (s): Joseph L. Fleiss 2014; 31(3): 651-9.

[36] Sriprakash A. Joyful Learning' in rural Indian primary schools: An analysis of social control in the context of child centred discourses 200937

[37] Geertz C. The religion of Java. London: The University of Chicago Press 1976

[38] Raffles TS. The history of Java. Cambridge, MA: Cambridge University Press 2010

[39] Sardiman S. Interaksi dan motivasi belajar mengajar Interaction and motivation of learning and teaching. Jakarta: Rajawali Pers 2012.

[40] Sofiyah S. Meningkatkan Kemampuan Membaca Permulaan dengan Menggunakan Media Gambar pada Siswa Kelas II SDN 2 Wosu Kecamatan Bungku Barat Kabupaten Morowali. J Kreat Tadulako Online 2014; 3(2): 1-12.

[41] Andriani S. Pembelajaran Membaca Permulaan Melalui Metode Ejabagi Siswa Berkesulitan Membaca (Disleksia) 2015; 1: 151-79. [Studi Kasus Mata Pelajaran Bahasa Indonesiadi Kelas Iii Madrasah Ibtidaiyah Quraniah Viii Palembang]. 
[42] Mile N. Peningkatan Kemampuan Membaca Permulaan Melalui Pembelajaran Konstruktivisme Dan Penggunaan Papan Flanel di Kelas I SD Negeri 1 Palu. J Kreat Tadulako Online 2016; 4(4)

[43] Heriantoko C. Peningkatan kemampuan membaca permulaan dengan media permainan maze pada anak tuna grahita ringan (increasing the ability of early reading with the game maze on mentally disabled children). J Pendidik Khusus 2013; 1(1): 1-17.

[44] Shirah CL. Autoethnographical inquiry into joyful teaching: explorations with national teachers of the year. 2006; p. 155.

[45] Kohn A. Turning Children into Data: A Skeptic's Guide to Assessment Programs. Educ Week 2010; 30(1): 29-32.

[46] Lee L. a Joyful Classroom Learning System With Robot Learning. 2011; 10: pp. (2)11-24.

[47] Ernestus M, Neijt A. Word length and the location of primary word stress in Dutch, German, and English. Linguistics 2008; 46(3): 507-40. [http://dx.doi.org/10.1515/LING.2008.017]

[48] Kuhn MR, Stahl SA. Teaching children to learn word meanings from context: A synthesis and some questions. J Literacy Res 1998; 30(1): 119-38.

[http://dx.doi.org/10.1080/10862969809547983]

[49] Nation P. Learning vocabulary in another language. Cambridge, MA: Cambridge University Press 2001.

[http://dx.doi.org/10.1017/CBO9781139524759]

[50] Curtin S. Young infants encode lexical stress in newly encountered words. J Exp Child Psychol 2010; 105(4): 376-85.

[http://dx.doi.org/10.1016/j.jecp.2009.12.004] [PMID: 20089259]

[51] Bryant PE, MacLean M, Bradley LL, Crossland J. Rhyme and alliteration, phoneme detection, and learning to read. Dev Psychol
1990; 26(3): 429-38

[http://dx.doi.org/10.1037/0012-1649.26.3.429]

[52] Stanovich KE. Speculations on the causes and consequences of individual differences in early acquisition.Reading acquisition. Hillsdale, NJ: Erlbaum 1992; pp. 307-42.

[53] Norris D, McQueen JM, Cutler A, Butterfield S. The possible-word constraint in the segmentation of continuous speech. Cognit Psychol 1997; 34(3): 191-243.

[http://dx.doi.org/10.1006/cogp.1997.0671] [PMID: 9466831]

[54] Ehri LC. Sjónrænn orðaforði. scientific studies of reading learning to read words: Theory, findings, and issues learning to read words: Theory, findings, and issues. Sci Stud Read ISSN 2005; 9(2): 167-88. [http://dx.doi.org/10.1207/s1532799xssr0902_4]

[55] Siantayani Y. Persiapan membaca bagi balita (Reading preparation for toddlers). Yogyakarta: Krizter Publiser 2011.

[56] Yopp HK, Yopp RH. Phonological awareness is child's play! YC Young Child 2009; 64(1): 12-21.

[57] Kyle FE, Harris M. Concurrent correlates and predictors of reading and spelling achievement in deaf and hearing school children. J Deaf Stud Deaf Educ 2006; 11(3): 273-88.

[http://dx.doi.org/10.1093/deafed/enj037] [PMID: 16556897]

[58] Gray CB. Topoi in Summa: Virtual justice as determinant for aquinas' placement of law. Int J Semiot Law 2006; 19(3): 325-38. [http://dx.doi.org/10.1007/s11196-006-9026-9]

[59] Lonigan CJ, Anthony JL, Phillips BM, Purpura DJ, Wilson SB, McQueen JD. The nature of preschool phonological processing abilities and their relations to vocabulary, general cognitive abilities, and print knowledge. J Educ Psychol 2009; 101(2): 345-58. [http://dx.doi.org/10.1037/a0013837] [PMID: 22180662]

\section{(C) 2019 Taufik et al.}

This is an open access article distributed under the terms of the Creative Commons Attribution 4.0 International Public License (CC-BY 4.0), a copy of which is available at: https://creativecommons.org/licenses/by/4.0/legalcode. This license permits unrestricted use, distribution, and reproduction in any medium, provided the original author and source are credited. 